\title{
lonotropic GABA receptors: modelling and design of selective ligands
}

\author{
Vladimir A Palyulin", EV Radchenko, DE Osolodkin, VI Chupakhin, NS Zefirov \\ From 5th German Conference on Cheminformatics: 23. CIC-Workshop \\ Goslar, Germany. 8-10 November 2009
}

Ionotropic $\mathrm{GABA}_{\mathrm{A}}$ and $\mathrm{GABA}_{\mathrm{C}}$ receptors play an important role in the operation of CNS and serve as targets for many neuroactive drugs. Using the homology modelling and molecular dynamics, the 3D models of the receptors were built and some aspects of ligandtarget interactions were elucidated [1,2].

To better understand the structural factors controlling the activity and selectivity of the ligands, a series of QSAR models [3] were derived based on the Molecular Field Topology Analysis (MFTA) [4], CoMFA and Topomer CoMFA approaches. They were compared with each other as well as with the molecular modelling results.

Finally, a number of potential selective ligand structures were identified by means of the virtual screening [5] from the available chemicals databases and the generated structure libraries.

Published: 4 May 2010

\section{References}

1. Osolodkin DI, Chupakhin VI, Palyulin VA, Zefirov NS: J Mol Graph Model 2009, 27:813.

2. Chupakhin VI, Palyulin VA, Zefirov NS: Doklady Biochem Biophys 2006, 408:169.

3. Chupakhin VI, Bobrov SV, Radchenko EV, Palyulin VA, Zefirov NS: Doklady Chemistry 2008, 422:227.

4. Palyulin VA, Radchenko EV, Zefirov NS: J Chem Inf Comp Sci 2000, 40:659.

5. Radchenko EV, Palyulin VA, Zefirov NS: Chemoinformatics Approaches to Virtual Screening RSCVarnek A, Tropsha A 2008, 150-181.

doi:10.1186/1758-2946-2-S1-P49

Cite this article as: Palyulin et al:: Ionotropic GABA receptors: modelling and design of selective ligands. Journal of Cheminformatics 2010 2(Suppl 1):P49.

\section{Publish with ChemistryCentral and every} scientist can read your work free of charge

"Open access provides opportunities to our colleagues in other parts of the globe, by allowing anyone to view the content free of charge." W. Jeffery Hurst, The Hershey Company.

- available free of charge to the entire scientific community

- peer reviewed and published immediately upon acceptance

- cited in PubMed and archived on PubMed Central

- yours - you keep the copyright

Submit your manuscript here:

http://www.chemistrycentral.com/manuscript/

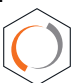
Chemistry Central 